Review

\title{
Focus on the Development of Natural Gas Hydrate in China
}

\author{
Zhongfu Tan, Ge Pan * and Pingkuo Liu \\ Economics and Management Department, North China Electric Power University, Beijing 102206, China; \\ tanzhongfubeijing@126.com (Z.T.); pingoforever@sina.com (P.L.) \\ * Correspondence:gegeabc@126.com; Tel.: +86-0351-61773118
}

Academic Editor: Andrew Kusiak

Received: 23 March 2016; Accepted: 13 May 2016; Published: 28 May 2016

\begin{abstract}
Natural gas hydrate, also known as combustible ice, and mainly composed of methane, is identified as a potential clean energy for the 21st century. Due to its large reserves, gas hydrate can ease problems caused by energy resource shortage and has gained attention around the world. In this paper, we focus on the exploration and development of gas hydrate as well as discussing its status and future development trend in China and abroad. We then analyze its opportunities and challenges in China from four aspects, resource, technology, economy and policy, with five forces model and Politics Economics Society Technology method. The results show China has abundance gas hydrate resource; however, backward technologies and inadequate investment have seriously hindered the future development of gas hydrate; thus, China should establish relevant cooperation framework and intuitional arrangement to attract more investment as well as breaking through technical difficulties to commercialization gas hydrate as soon as possible.
\end{abstract}

Keywords: natural gas hydrate; five forces model; intuitional arrangement

\section{Introduction}

\subsection{Background}

Natural gas hydrates, which remain stable at low temperature and high pressure, are usually deposited in permafrost areas, seabed, and lake sediment [1]. As a new emerging energy with abundant reserve, natural gas hydrate not only has high combustion value, but also is environment friendly [2]. Therefore, as global energy resources continue to be depleted, research on gas hydrate is valued by countries across the world, and it may become a substitute for conventional energy sources, including coal, petroleum and natural gas.

Thus far, more than 30 countries have carried out research and exploitation on gas hydrate, and many countries have made long-period gas hydrate development strategies and large national projects, listed gas hydrate projects, trial exploitation and related technical research in the fiscal budget. Some countries such as The United States, Japan, Canada and China have made their own gas hydrate commercial production schedule [3]. Among those, the United States, Japan and Canada take the leading position on gas hydrate basic research, drilling test and many other aspects. The successful trial exploitation in Canada permafrost region carried out by United States, Canada, Japan and Germany, which happened in 2002 is a sign that the world's utilization and exploitation of gas hydrate has entered a new stage. At the same time, Japan promulgated the "Japan gas hydrate research plan" in 2001 and it is currently in the second stage of this research plan. From 2009 to 2015, Japan mainly studied natural gas extraction from gas hydrate method and made technical preparation for commercial production. In 2013, Japan has conducted a submarine gas hydrate extraction experiment successfully and became the first country to master submarine gas hydrate exploitation technology. Japan is planning to 
realize commercial production in 2018 [4]. However, due to high exploitation cost and damage to the environment, large-scale gas hydrate exploitation is unlikely to be realized soon.

Gas hydrate has abundant reserve and bright development prospects in China. In order to optimize the energy structure and relieve the problems caused by energy shortage, it is of great urgency to replace conventional energy (coal, oil, etc.) with new clean energy. Recently, China pays much attention to gas hydrate exploitation. In May 2007, China successfully acquired a physical gas hydrate sample and became the fourth country able to extract a physical sample of gas hydrate following the United States, Japan and India. In 2013, the development planning of exploitation and production of Gas hydrate is included in "National 863 plan project" to speed up related research. Generally speaking, research on gas hydrate starts in China started late but has been developing rapidly. It is estimated that China will complete the initial preparation work for commercial production by 2020, including mining technologies and evaluation of seabed natural gas hydrate. China will carry out marine commercial production test from 2021 to 2035 and large-scale marine commercial production from 2036 to 2050 [5].

To analyze development and provide future strategies of domestic natural gas hydrate industry, this paper introduces the current situation of gas hydrate development in China from policy, technology, reserves and other aspects; development prospect; and institutional prospect will be analyzed, including cooperation and policy framework. The rest of this paper is organized as follows: the remainder of Section 1 mainly introduces domestic and international development of gas hydrate; Section 2 introduces the current situation in China; Section 3 analyzes development potential of gas hydrate in China; Section 4 outlines the development framework; and Section 5 provides the conclusion.

\subsection{Literature Review}

\subsubsection{Technology}

Since the first gas hydrate reservoir was discovered in the 1960s, countries with limited energy resources and increasing energy consumption have competed in the research field; research on natural gas hydrate exploitation and exploration entered its peak period in the 21st century [6]. Currently, scientists all over the world are carrying out research on natural gas hydrate and have made achievements in physical and chemical properties, reservoir forming condition and modeling, structure type, resource evaluation method, exploitation and investigation technology, global climate change, marine geology disasters, etc. [7].

China's natural gas hydrate research started in Northern South China Sea, followed by research in the East China Sea, permafrost regions in the Tibetan Plateau and Mohe. For prospective area delineation, remote sensing, geophysical prospecting and chemical prospecting are widely used methods for detecting the existence of hydrates through basic geology and hydrocarbon accumulation survey. An et al. found that natural gas hydrates resources of permafrost regions are mainly distributed in Mohe Basin and Qinghai-Tibet Plateau as well as distributed dispersedly in some plateau regions in western China. An et al. [8], Lu et al. [9] and Zhu et al. [10] considering gas resources, transportation and reservoir condition, proposed that Qiangtang Basin is the best prospective region for gas hydrate, followed by Qilian Mountains and Fenghuoshan-Wuli region. Natural gas hydrate in Qilian Mountains is speculated to be a new type of hydrate. Based on influencing factors of natural gas hydrate formation, Wei [11], Nguyen Nhu Trung [12] thought the South China Sea is favorable for natural gas hydrate formation when considering temperature, pressure, tectonic evolution, petroleum geological condition, etc. Total area of the gas hydrate stability zone is $1.1 \times 10^{6} \mathrm{~km}^{3}$. In addition, the northeast continental slope of South China Sea is expected to be the region with the richest gas hydrate reserve. Gong et al. [13] analyzed Shenhu Sea area from perspective of hydrocarbon accumulation, and then pointed out the huge rocks from Baiyun Sag are the main substance resources; therefore, Shenhu Sea area is a better gas hydrate prospecting area because of its favorable conditions. 
For resource potential and reserve evaluations, Zhu et al. [14] estimated that natural gas hydrate in domestic permafrost region is approximately $38 \times 10^{12}$ cubic meters, which is equal to $380 \times 10^{8}$ tons of oil equivalents by using volume method and Monte Carlo method. Lu et al [15] calculated natural gas hydrate reserve in Qilian Mountains with volume method. The total reserve quantity is approximately $94.2 \times 10^{4}$ cubic meters. Wang et al. [16] pointed out natural gas hydrate reserve in northern continental slope of South China Sea is approximately 18.5 billion tons of oil equivalents, which is six times as much as the proven oil and gas reserves in South China Sea.

For natural gas hydrate reservoir-forming rules, some scholars argued that reservoir-forming system should be paid more attention to combine hydrocarbon source transportation and gas hydrate reservoir-forming into one system [17], Mohebbi [18] supposed that the kinetics is the most challenging question about the source. Besides, dissociation and inhibition of gas hydrates, heat and mass transformation of hydrate formation make hydrate kinetics difficult to predict. Su [19] built a one-dimension kinetic model on reservoir-forming process in Shenhu Area; however, the modeled result based on current sedimentation rate and water flow rate is quite different from actual data, which imply the reservoir-forming trend of natural gas hydrate content. Zhu et al. [20] analyzed basic characteristics of natural gas hydrate in Qilian Mountain permafrost region from perspective of lithology, structure, and strata. They supposed that natural gas hydrate in Qilian Mountain is a new type of hydrate, which is buried in a relatively thin layer.

For the study of natural gas hydrate mining technology, due to condition constraints, most research is limited to theoretical research for now. There are four main methods [21], thermal stimulation method, depressurization method, inhibitor injector (such as salts and alcohols) method, and a combination of these methods. Among them, depressurization and thermal simulation method are considered as relatively feasible methods, both economically and technically. Chong et al. introduced a method that produces methane via the exchange between $\mathrm{CO}_{2}$ and $\mathrm{CH}_{4}$; in this method, $\mathrm{CO}_{2}$ is injected into natural gas hydrate reserve area to release methane. However, there are still some challenges on kinetics of methane production from $\mathrm{CO}_{2}$ injection and $\mathrm{CO}_{2}$ formation, and the deep understanding of the replacement process [22]. Chen et al. [23] proposed that the volume of energy return on energy invested (EROI) can be regarded as an indicator of natural gas hydrate exploitation efficiency; improved technologies can help to increase the exploitation efficiency. Janicki et al. [24] concluded from the German research project that reservoir permeability and available heat have important effects on hydrates decomposition. In addition, their experiments were carried out to show that depressurization is a practical way to produce methane from seabed gas hydrates.

\subsubsection{Economy}

Global gas hydrate research is still in its infancy; an industrial chain has not yet been formed, so there is plenty of room for future development. Sun et al. [6] divides the industry chain of gas hydrate into upstream, midstream and downstream. Among them, upstream firms are large enterprises that are responsible for related investment and research about technology in exploration and exploitation fields. Efficient gas transformation after mining offers opportunities for midstream enterprises. Natural gas can be used in transportation, metallurgy, electric power industries and provide huge commercial value for downstream enterprises. For the current technical level, cost of natural gas gained from gas hydrate exploitation is higher than other ways. However, there are some advanced methods to reduce drilling cost and enhance drilling efficiency. Zhang et al. [25] suggested that a reserve circulation method could be used in oceanic survey, with dual well drilling pipe and low temperature mud in close circulation to decrease the drilling and coring cost. MH21, a research consortium for methane hydrate resources in Japan analyzed more than 10 production methods, including thermal decomposition, decompression, carbon dioxide displacement method, and found that the most efficient and economic method is determined to be decompression for production [26]; however, exploitation cost is equivalent to two times the import price of Japan LNG. Luo et al. [27]. pointed out exploitation cost of gas hydrate is up 
to $\$ 200 / \mathrm{m}^{3}$, which is equivalent to a natural gas (per cubic meter) cost of more than one dollar, much higher than shale gas.

\subsubsection{Environment}

Even though gas hydrate has wide development prospect, its production may cause a series of environmental problems, mainly including geological disaster, damage of undersea environment, global warming phenomenon, etc. For geological disaster, Zhang [28] proposed the water produced during continental gas hydrate mining process may dilute strata space and make underling structure unstable, so it is easier to cause geological disaster. Submarine gas hydrate exploitation easily decreases seabed stability and might even induce submarine landslide. Rutqvist et al. [29] and Liu et al. [30] concluded that submarine gas hydrate exploitation will produce tremendous pressure at the instance of release, which might damage the undersea environment and even cause earthquake and tsunami. For submarine ecological balance, Zhang [31] pointed out releasing methane into the sea during the oil and gas drilling engineering process would increase carbon dioxide proportion in water, and the undersea ecological balance would be damaged as a result. For global warming phenomenon, natural gas hydrate's main composition is methane, whose greenhouse effect is 21 times that of carbon dioxide. Methane might be released during exploitation due to carelessness; if methane decomposed from gas hydrate were to reach $0.5 \%$ of methane in the atmosphere, the greenhouse effect would intensify.

\section{Current Situation}

\subsection{Reserves}

Coal is the core of the Chinese energy structure, and it is estimated that this situation is unlikely to change in the next few years. In 2014, domestic energy consumption was 4.26 billion tons of standard coal equivalents. Compared with 2013, natural gas consumption increased by $8.6 \%$, while coal consumption fell by $2.9 \%$, but still accounted for $66 \%$ of total energy consumption [32]. It is estimated that proven reserves of coal resource can be used for only 100 years in the future. Thus, in today's growing shortage of conventional energy, new energy such as gas hydrates can not only change domestic energy structure to some extent, but also play an important role in realizing energy sustainable development strategy proposed in the twelfth Five-Year Plan.

There is abundant gas hydrate reserve in China and it has been proven with abundant reserves in deep water or mountain permafrost regions. However, due to low exploration degree and uncertain evaluation parameters, current estimation of domestic gas hydrate reserve is still inconclusive. There is great difference between the estimation between different research institutions and experts. According to incomplete estimates, total gas hydrate reserve in China is about 84 trillion cubic meters [31], mainly distributed in the East China Sea, South China Sea, Qinghai-Tibet Plateau permafrost and Northeast China permafrost. Figure 1 illustrates recovered and referred natural gas hydrate distribution in China.

Wherein, according to the estimations made by experts, gas hydrate reserved in The East China Sea, South China Sea, Qinghai-Tibet Plateau and Northeast China permafrost are 3.38, 64.96, 12.5 and 2.8 trillion cubic meters respectively [33].The preliminary estimation of China permafrost region gas hydrate reserve is 38 trillion cubic meter, which is 38 billion tons of oil equivalents [34]. The accuracy of these data will increase with more exploration studies and evaluation information.

Figure 2 illustrates the proportion of four enrichment regions showing the South China Sea as the region with the most abundant reserve. Therefore, China is currently increasing its gas hydrate research efforts in the South Sea and Qinghai-Tibet Plateau. In the north region of the South Sea, Guangzhou Marine Geological Survey carried out investigation activities over four deep water regions and announced the gas hydrate reserve is 18.5 billion tons of oil equivalents. 


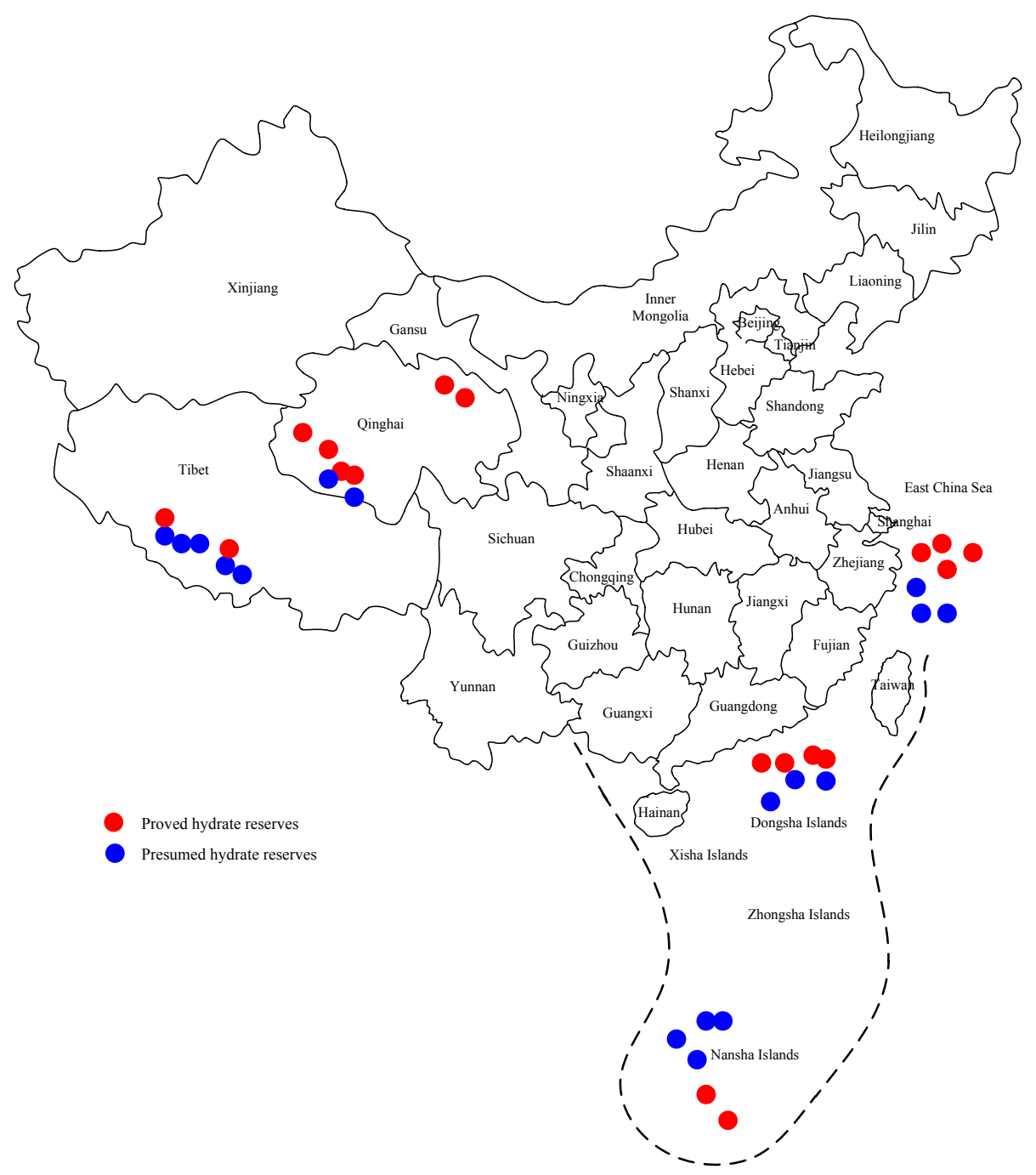

Figure 1. Proved methane hydrate deposits distribution.

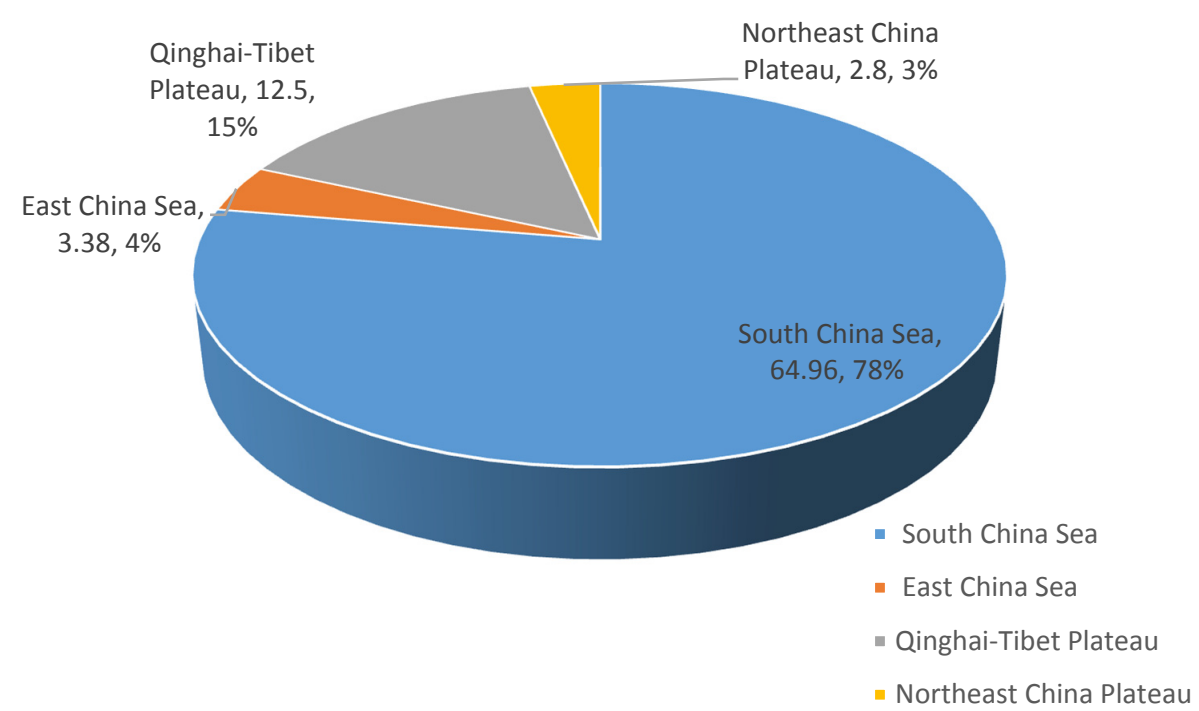

Figure 2. The proportion of domestic combustible ice area with abundant reserve. 


\subsection{Technological Aspects}

Currently, global natural gas hydrate mining is still at the experimental level. The U.S. and Japan have already completed trial mining; however, there is no perfect and reliable mining method yet. Existing methods have disadvantages such as low production efficiency, high mining condition, expensive material implement, environmental risks, etc. For China, technical level is lagging behind those developed countries. Many techniques and investigation equipment heavily rely on importation. Nowadays, China focuses on further exploration and evaluation for rich regions of natural gas hydrate, and makes preparation for trial mining and commercial production. China is estimated to enter large-scale commercial production stage by 2036-2050. Table 1 shows major events of global natural gas hydrate research. It reflects the gap between China and other countries in the technology aspect. It is worth noting that Messoyakha Gas Field in Russia, discovered in the late 1960s, is the only hydrate field that has realized commercial gas hydrates production.

Table 1. Global natural gas hydrate development.

\begin{tabular}{|c|c|c|c|}
\hline State & Drilling Experiment & Trial Mining & Commercial Production \\
\hline The United States & $\begin{array}{l}\text { In 2009, the U.S. completed } \\
\text { drilling and logging project in } \\
\text { Gulf of Mexico successfully. }\end{array}$ & $\begin{array}{l}\text { In 2012, the U.S. Department of } \\
\text { Energy discovered natural gas } \\
\text { hydrate in North slope of Alaska } \\
\text { and obtained steady flow of } \\
\text { natural gas [35]. }\end{array}$ & After 2016 \\
\hline Japan & $\begin{array}{l}\text { In cooperation with Canada and } \\
\text { the U.S., Japan carried out } \\
\text { drilling experiment in } \\
\text { Mackenzie delta and gains the } \\
\text { sample of natural gas hydrate. }\end{array}$ & $\begin{array}{l}\text { In 2013, Japan acquired natural } \\
\text { gas from natural gas hydrate in } \\
\text { Atsumi Peninsula and } \\
\text { Shima Peninsula }\end{array}$ & $\begin{array}{l}\text { After } 2018 \text { according } \\
\text { to estimation }\end{array}$ \\
\hline China & $\begin{array}{l}\text { In 2007, China found gas } \\
\text { hydrate sample in Northern } \\
\text { South China Sea for the first } \\
\text { time [36]. In 2009, China } \\
\text { successfully drilled out physical } \\
\text { sample in Qilian Mountains and } \\
\text { become the first country to } \\
\text { discover natural gas hydrate in } \\
\text { low-latitude permafrost } \\
\text { zone [37]. In 2013, China gained } \\
\text { sample of new type in } \\
\text { Northern South China Sea. }\end{array}$ & After 2020 & After 2036 \\
\hline Canada & $\begin{array}{l}\text { In 1998, Canada performed } \\
\text { drilling activities in Mallik } \\
\text { 2L238 well and drilled out } \\
\text { natural gas hydrate core. }\end{array}$ & $\begin{array}{l}\text { In 2002, Canada carried out trial } \\
\text { mining experiments in } \\
\text { Mackenzie delta in cooperation } \\
\text { with Japan. Besides, Canada } \\
\text { completed terrestrial methane } \\
\text { hydrate production tests from } \\
2001 \text { to } 2008 \text {. }\end{array}$ & $\begin{array}{l}\text { In 2013, Canada } \\
\text { Government announced } \\
\text { abandoning natural gas } \\
\text { hydrate development }\end{array}$ \\
\hline
\end{tabular}

\subsubsection{Natural Gas Hydrate Detection Technology}

Marine gas hydrate can be detected not only by marine sediment sampling and analysis, drilling and deep submersion investigation directly, but also indirectly detected by seismic geophysical including bottom simulating reflector (BSR); blanking zone, amplitude versus offset (AVO) structure [38]; geochemical anomaly including anomaly increased sea surface temperature, gas geochemical analysis and mineral research signs; multi-wave velocity bathymetry; and underwater camera. These above mentioned techniques have been widely used in northern South China Sea. Currently, BSR is the main assessment technique for seabed natural gas hydrate reserves all over the world. For natural gas hydrate in permafrost region, China has developed a set of field investigation 
and exploitation method with drilling as primary channel while geophysical, geochemical and analytical testing as supplement.

In marine gas hydrate detection field, China established a comprehensive natural gas hydrate detection technology system, including submarine electromagnetic technology, the 3-D seismic and Ocean Bottom Seismometer (OBS) joint exploration technology, etc. Among them, OBS can be applied to detect natural gas hydrate and estimate its reserve [39]. Figure 3 illustrates its working principle; velocity of wave $p$ and wave $s$ are recorded to speculate gas hydrate existence.

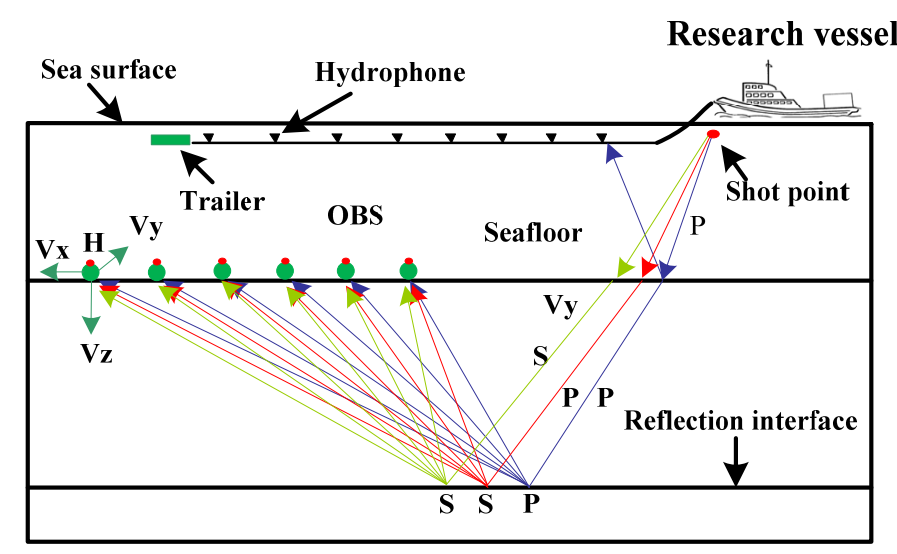

Figure 3. The sketch of integrated 3-D seismic and Ocean Bottom Seismometer exploration and converted wave geometry in the environment [39]. (Copyright: Zhang, G.; Xu, H.; Liu, X.; Zhang, M.; Wu, Z.; Liang, J.; Wang, H.; Sha, Z. The acoustic velocity characteristics of sediment with gas hydrate revealed by integrated exploration of 3D seismic and OBS data in Shenhu area. Chin. J. Geophys. 2014, 57, 1169-1176.)

Marine controlled electromagnetic technology (CSEM) can measure seafloor electrical resistivity by sending and receiving electromagnetic signal seafloor [40]. As illustrated in Figure 4, this detecting technique can obtain volume resistivity and content of gas hydrate as well as efficiently improve drilling success rate.

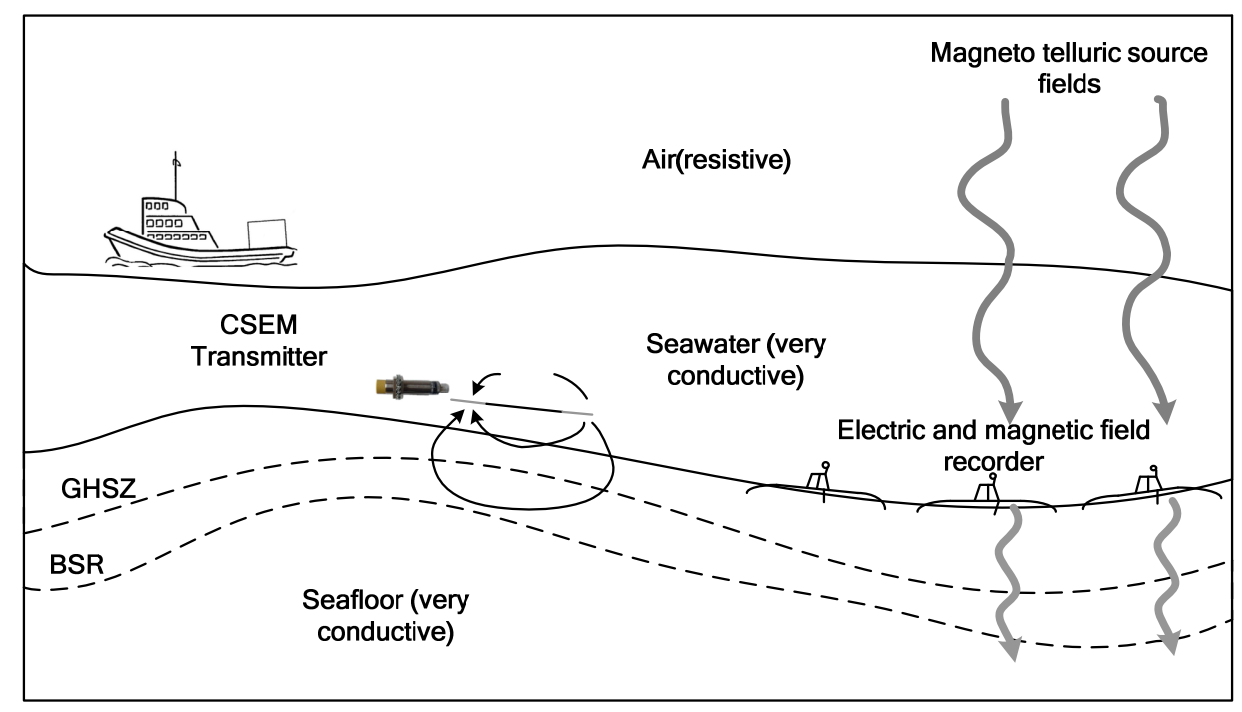

Figure 4. Marine controlled electromagnetic technology using a horizontal towed dipole source for gas hydrates exploration (revise from [41].) 
In acoustic research field of deep-tow technology, an acoustic deep-tow system at the 3000-meter level was assembled successfully and carried out underwater test for the first time in early 2016. This system can not only detect micro topography and submarine shallow layer structure, but also obtain basic geochemical data and information. In addition, this self-innovated system provides strong technical support for marine gas hydrate detection.

\subsubsection{Natural Gas Hydrate Reservoir-Forming Mechanism}

The formation and stability of natural gas hydrate require low-temperature and high-pressure environment. Gas hydrate stability zone can control its mineralization, distribution law and evolution process. In addition, the stability zone is controlled by several factors of gas hydrate petroleum system, such as geothermal gradient, seafloor temperature, pressure, gas composition, pore water salinity, gas source, gas migration and reservoir [42].

The reservoir system for natural gas hydrate is very complicated. China's geological modes of natural gas hydrate reservoir forming are established on perspective of reservoir-forming mechanism, gas resource and kinetics in foreign countries. However, some key issues are unsolved. The majority of domestic research on reservoir-forming mechanism focuses on some particular aspects. Chinese scholars divide reservoir -forming mode of gas hydrate into three types: diffusion of local biogenic gas, leakage of migrated thermocatalytic pyrolitic gas, and mixed type of biogenic gas and thermo catalytic gas. The diffusion type of local biogenic gas is the most common.

\subsubsection{Natural Gas Hydrate Mining Technology}

Current natural gas hydrate mining technology is still in its sampling stage; trial mining experiment has not been carried out yet. In hardware aspects, experimental apparatus designed by China University of Petroleum can investigate reservoir formation scope and simulate various reservoir formation modes and evolution processes. Natural gas hydrate development device built by Guangzhou Marine Geological Survey can measure dynamic characteristics during exploitation process. In software aspects, simulation software for natural gas hydrate can make simulation research on different mining methods such as thermal simulation, depressurization, inhibitor injection, etc. The software can be applied to complex geological conditions, such as porous media and fissured structure, which can offer a basis for natural gas hydrate exploitation.

For mining methods, there are traditional methods including thermal stimulation method, depressurization method and inhibitor injection method. With further research on exploitation, $\mathrm{CO}_{2}-\mathrm{CH}_{4}$ replacement method and solid mining method were developed. Table 2 shows natural gas hydrate mining methods and their principles. China has made innovative achievement in marine gas hydrate mining devices and techniques. Moreover, China has made progress in solid mining method and proposed hydraulic lifting method [43]. Figure 5 illustrates the system structure of hydraulic lifting method of mining natural gas hydrate in the South China Sea.

Table 2. Natural gas hydrate mining method and principle.

\begin{tabular}{ll}
\hline \multicolumn{1}{c}{ Mining Method } & \multicolumn{1}{c}{ Mining Principle } \\
\hline Thermal stimulation method & Change temperature condition for gas hydrate phase equilibrium \\
\hline Depressurization method & Change pressure condition for gas hydrate phase equilibrium \\
\hline Inhibitor injection method & Change pressure/temperature condition for gas hydrate phase equilibrium \\
\hline $\mathrm{CO}_{2}-\mathrm{CH}_{4}$ replacement method & $\mathrm{CO}_{2}$ requires lower energy to form hydrate compared with $\mathrm{CH}_{4}$ \\
\hline Solid mining method & Maintain the original state \\
\hline
\end{tabular}




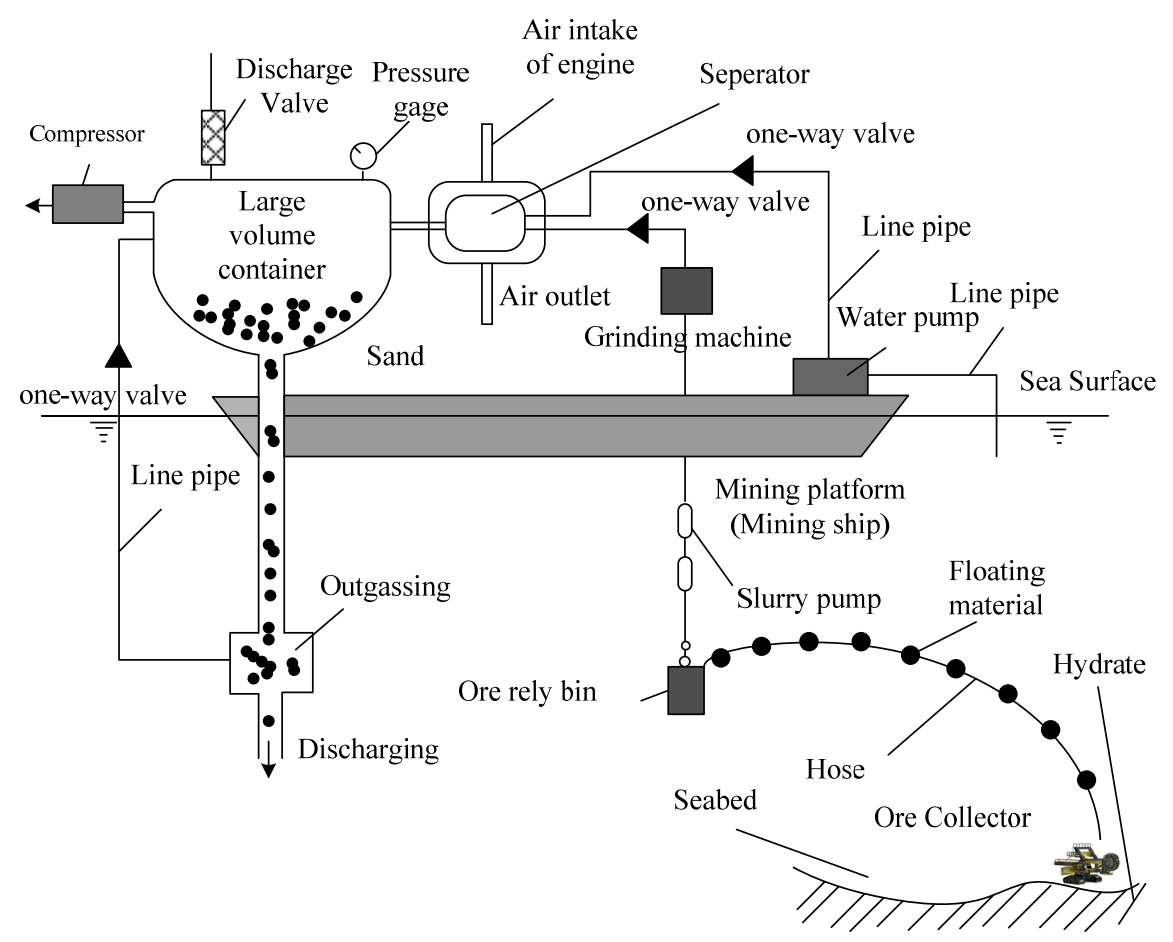

Figure 5. The system structure of hydraulic lifting method of mining gas hydrate [43]. (Copyright: Yang, J.; Zeng, F.; Cheng, H.; Gao, J. Hydraulic lifting mining method for gas hydrate exploitation in the South China Sea. Henan Sci. 2015, 33, 785-790.)

\section{Development Potential Analysis}

\subsection{Strengths Weaknesses Opportunities Threats and Polictics Economics Society Technology Analysis}

SWOT analysis can determine competitive advantages, disadvantages, opportunities and threats, while PEST analysis refers to external environment analysis of certain industry. SWOT and PEST analysis is an innovative method that can identify internal and external influencing factors of industry development. It will provide proper information for industry strategy.

As shown in Table 3, we have analyzed development status of gas hydrate in China with SWOT and PEST model. Specific policy, economy, social and technology analysis of gas hydrate follows.

Strengths of politics: The Chinese government attaches great importance to exploitation and exploration of gas hydrate and regard it as one of the strategic reserve resources. Gas hydrate development is included in "863 plan" and "973 plan" as well as "the twelfth five-year plan for natural gas development" is promulgated to strengthen gas hydrate development.

Weaknesses of politics: There are no particular laws or regulations unveiled for gas hydrate; current laws have no pertinence. China lacks policies and regulations on gas hydrate exploitation and utilization. Moreover, there are still no professional governmental authorities responsible for this field of engineering and technology, and no specific plan and industrial program for future related industry development.

Opportunities of politics: In the "National long-term science and technology development plan (2006-2020)", gas hydrate is included as one of the advanced techniques. The Chinese government has established gas hydrate key laboratory to cultivate professionals and introduce related experts from abroad, especially from the United States and Japan, which has established sound legal system and made adequate investments to carry out long-term research plan. However, some countries such as Japan refuse to cooperate with China in the gas hydrate field.

Threats of politics: Research on gas hydrate is highly valued in the world, there are more than 30 countries and regions kept conducting related research and survey in this field, many countries 
regard exploitation technology as highly confidential. The competition is fierce; countries including Japan and the United States have included exploration and exploitation of natural gas hydrate into long-term national energy program, while China lacks an overall plan.

Table 3. SWOT-PEST analysis for gas hydrate development in China.

\begin{tabular}{|c|c|c|c|c|}
\hline & Strengths & Weaknesses & Opportunities & Threats \\
\hline Political & $\begin{array}{l}\text { The Chinese } \\
\text { government } \\
\text { attaches great } \\
\text { importance to gas } \\
\text { hydrate } \\
\text { development. }\end{array}$ & $\begin{array}{l}\text { China has no solid } \\
\text { legal system, no } \\
\text { related competent } \\
\text { authorities and } \\
\text { comprehensive } \\
\text { development plan. }\end{array}$ & $\begin{array}{l}\text { Gas hydrate } \\
\text { development is included } \\
\text { in several long-term } \\
\text { development programs } \\
\text { to } 2020 \text {. }\end{array}$ & $\begin{array}{l}\text { The national } \\
\text { competition is fierce. } \\
\text { Some countries } \\
\text { refuse to cooperate } \\
\text { with China. }\end{array}$ \\
\hline Economic & $\begin{array}{l}\text { Huge financial } \\
\text { support given by } \\
\text { the Chinese } \\
\text { government. }\end{array}$ & $\begin{array}{l}\text { There is still a long } \\
\text { way to produce } \\
\text { natural gas } \\
\text { commercially. }\end{array}$ & $\begin{array}{l}\text { China has a gas hydrate } \\
\text { market with wide and } \\
\text { bright prospect. }\end{array}$ & $\begin{array}{l}\text { Gas hydrate } \\
\text { exploitation is not } \\
\text { the most economical } \\
\text { way to obtain } \\
\text { natural gas. }\end{array}$ \\
\hline Social & $\begin{array}{l}\text { Gas hydrate is } \\
\text { regarded as ideal } \\
\text { low carbon energy } \\
\text { in the future. }\end{array}$ & $\begin{array}{l}\text { Gas hydrate is not } \\
\text { able to replace coal } \\
\text { or natural gas in } \\
\text { upcoming years. }\end{array}$ & $\begin{array}{l}\text { Gas hydrate can finally } \\
\text { be recognized as one of } \\
\text { the main energy } \\
\text { resources in China. }\end{array}$ & $\begin{array}{l}\text { Problems regarding } \\
\text { how to balance } \\
\text { environmental } \\
\text { protection and } \\
\text { energy security are } \\
\text { still unresolved. }\end{array}$ \\
\hline Technology & $\begin{array}{l}\text { China has become } \\
\text { one of the few } \\
\text { countries that have } \\
\text { mastered related } \\
\text { key technologies. }\end{array}$ & $\begin{array}{l}\text { Research started } \\
\text { relatively late, and } \\
\text { related technology } \\
\text { is immature }\end{array}$ & $\begin{array}{l}\text { Reservoir-forming } \\
\text { mechanism, enrichment } \\
\text { regularity and other } \\
\text { techniques are in the } \\
\text { industry forefront. }\end{array}$ & $\begin{array}{l}\text { Domestic technical } \\
\text { level lags behind } \\
\text { other countries. }\end{array}$ \\
\hline
\end{tabular}

Strengths of politics: Driven by the worry of limited domestic energy resources and energy storage, China is now attaching increasing importance to research on gas hydrate. Natural gas hydrate is included in a major national energy development strategy; the research investment is 820 million yuan.

Weaknesses of economics: The cost of natural gas produced from gas hydrate is much higher than other ways; few domestic enterprises have gas hydrate production service and most enterprises are waiting for mature and economical technology. There is still a long way for a complete commercial production mode of natural gas hydrate.

Opportunities of economics: Domestic demand for natural gas has been increasing these years, in 2015, domestic natural gas consumption is 193.2 billion cubic meters, and 61.4 billion cubic meters are imported from other countries. Domestic Natural gas consumption, production, import and export from 2006 to 2012 can be seen in Figures 6 and 7. Moreover, it is estimated that the gap between supply and demand will expand further in the future, so the potential market for combustible fuel is large. Formal commercial production will likely commence after 2036, as estimated by related research projects.

Threats of economics: Domestic unconventional gas develops rapidly; tight gas and coal-bed gas have entered commercial production period and scale production stage. From the perspective of technical level and economic benefit, they have the priority to accelerate development before gas hydrate.

Strengths of society: In recent years, China has been promoting new clean energy and sticking to the sustainable development mode. China has abundant reserve of gas hydrate, which is regarded as ideal resource in low-carbon society.

Weaknesses of society: As a type of new energy, there is a lack of overall understanding about the use and future potential of gas hydrate from the whole society. Few people are experts on gas hydrate. Nowadays, with the appearance of haze problem, people are now gradually aware of environmental 
protection. However, the damage to the environment brought by gas hydrate is still unclear. Due to immature key technologies, there is still a long way to get social acceptance.

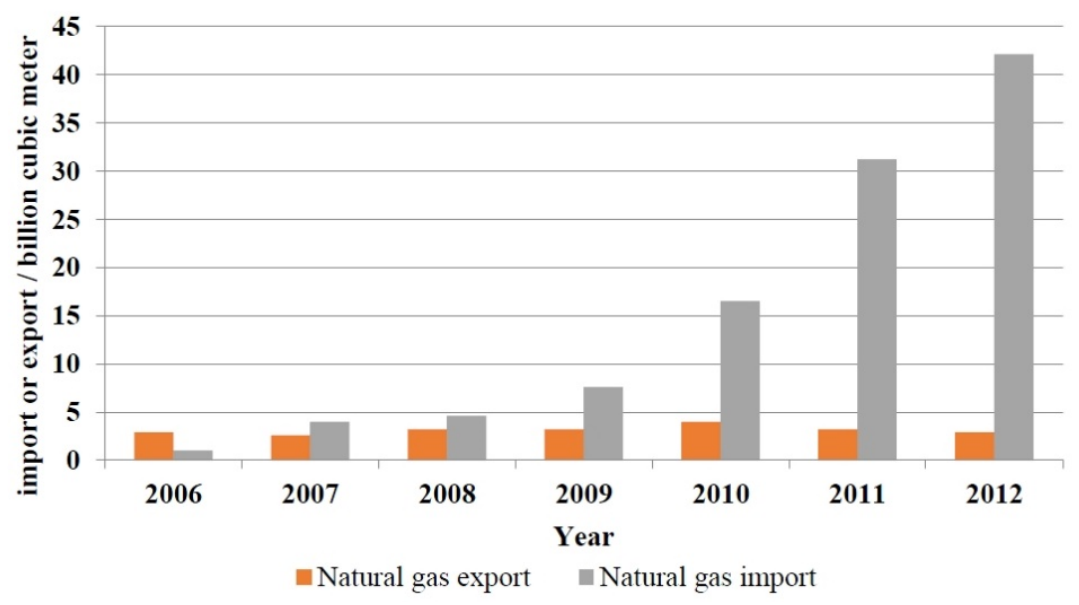

Figure 6. China's natural gas export and import.

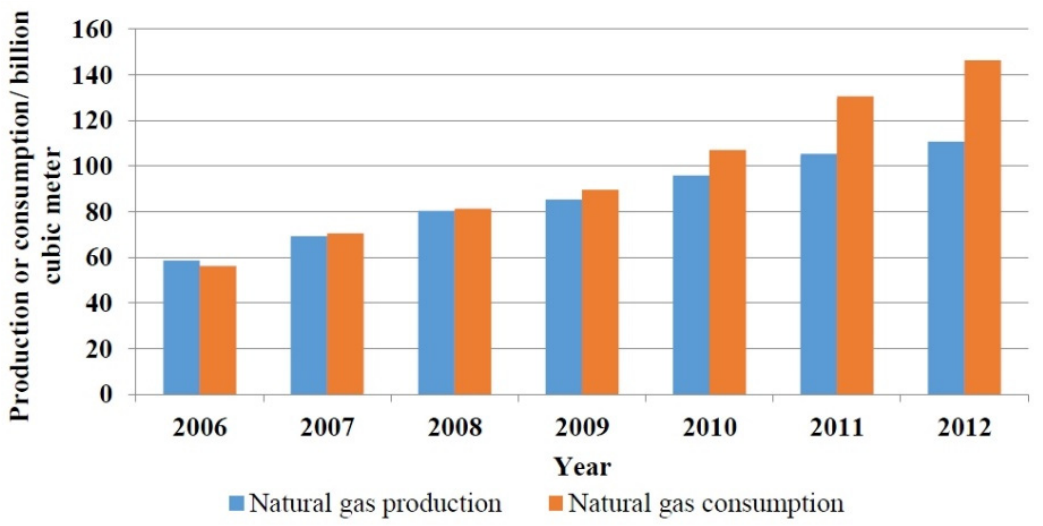

Figure 7. China's natural gas production and consumption.

Opportunities of society: Domestic energy structure is heavily dependent on coal, but there are more and more inclinations to use natural gas. Enterprises that have gas hydrate services do not exist in the short term; however, under the sustainable development strategy of the government, people will attach greater importance to gas hydrate.

Threats of society: Gas hydrate exploitation may intensify global warming phenomenon, damage marine ecosystem and even cause earthquake and tsunami and other disasters, like the disaster in Fukushima. Gas hydrate will suffer from public resistance and doubt during its early development stage.

Strengths of technology: China is the fifth country in the world to acquire the technology to obtain gas hydrate of its primitive form, and one of the few countries that is able to handle related techniques. China has made progress in resource investigation, exploitation techniques, basic theory and trial mining fields. China was the fourth country to extract a physical sample of gas hydrate, after the United States, Japan and India.

Weaknesses of technology: Domestic technical level is now lagging behind other countries, regarding the formation mechanism and reservoir-forming mechanism, and the migration path of gas hydrate is still unclear. Meanwhile, basic elements of gas hydrate actual reserve and commercial production scale is uncertain. Its exploitation lacks complete theoretical guidance. 
Opportunities of technology: National authorities, research institutions and enterprises have done many studies and accumulated much basic information and test experience; besides reservoir-forming theory, investigation methods are getting enriched. Domestic research institutions have been carrying out investigations about related equipment to get rid of dependence on foreign products.

Threats of technology: Domestic gas hydrate development lags five or six years behind that of Japan and the United States. Compared with developed countries, there is a great gap in laboratory simulation, basic theory, investigation evaluation research, drilling equipment and technology, experimental area choice, and so on.

\subsection{Competitive Analysis}

Figure 8 illustrates Porter's five forces model, or the five forces that determine the main competitive resources of an industry: existing competitors, potential competitors, bargaining power of customers, bargaining power of suppliers and threat of substitution. It is used to analyze competitiveness and attractiveness of domestic gas hydrate industry.

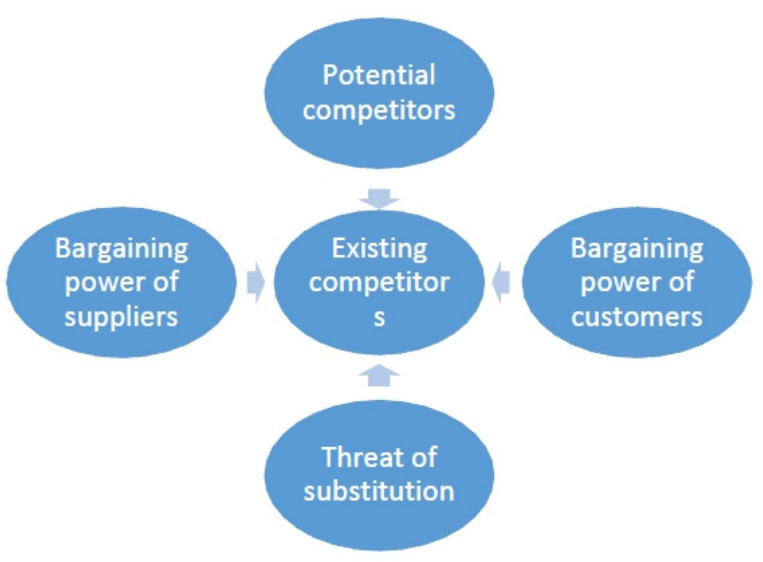

Figure 8. China's natural gas production and consumption.

\subsubsection{Existing Competitors}

The existing competitors of gas hydrate are conventional energy, including coal, oil and conventional gas, which have realized commercial production for many years. Conventional energy has mature technology on investigation drilling and mining. In addition, controlled by National Energy Administration, they already have mature market mechanisms and a solid legal system. With the total energy consumption reaching 4.26 billion tons of standard coal in 2014, China has become the largest energy consuming country in the world. However, domestic energy structure is highly dependent on coal; coal consumption in 2013 accounts for $67.5 \%$ of total energy consumption, while oil consumption is $17.8 \%$. It is estimated by experts that coal reserves in China will be depleted in approximately 2049; conventional gas and oil are in peril of depletion as well. In addition, conventional energy production cannot meet rapid demand in China. The reliance on importation has been increasing these years. Geopolitical disturbances can create fluctuations in the supply and can have a serious impact on the import costs. Fluctuation in conventional energy prices has significant effect on the GDP of China. Therefore, in the short term, conventional gas is the existing competitor of gas hydrate. However, as a long-term strategy, if we overcome difficulties in technology, funds and environment, natural gas hydrate will be ideal energy.

\subsubsection{Potential Competitors}

The potential competitors of gas hydrate are coal-bed methane (CBM), tight gas and shale gas. They all belong to unconventional gas and have abundant reserves and mature technology; their 
production exceeds a quarter of natural gas production. Among them, tight gas and coal-bed gas have entered commercial production stage; domestic CBM production in 2015 was 4.4 billion cubic meters, but daily production of single well production is low. Besides, its scale production lacks theoretical guidance. The policies related to attracting investment need to be improved, while government intervention could stimulate the interest of private investors. For shale gas, its reserve in China ranks first in the world. The Chongqing shale gas field has the second largest reserves, and realized large-scale commercial production, with annual production up to 5 billion cubic meters. According to China's National Development and Reform Commission's shale gas development plan, shale gas production should be 6.5 billion cubic meters in 2015 and shall reach 60 to 100 billion cubic meters by 2020 . To achieve this goal, 20,000 more shale wells need to be drilled, which requires a massive investment of 95 Billion USD [44]. In addition, shale gas development is facing high mining cost, large water consumption, water pollution and other issues. Therefore, unconventional gas (except gas hydrate) needs support in policies and funding as well to accomplish related technological breakthroughs. Unconventional gas, which acquires mature technology and complete industrial chain, will impose less effect on the environment, and thus will be the priority for development in the near future.

\subsubsection{Bargaining Power of Customers}

Compared with conventional gas, gas produced from gas hydrate has no competitive advantage on price, which might increase risk of investment recovery. This situation will make it difficult for investors to apply for financing from banks. Therefore, for small- and medium-sized enterprises, they have a wide range of choices to purchase natural gas and bargaining power is strong. However, driven by risks of energy shortage, technical breakthroughs and government support, the bargaining power of small- and medium-sized enterprises will decrease in the long term.

\subsubsection{Bargaining Power of Suppliers}

In China, natural gas pipelines and city gas pipelines are monopolistic and controlled by large state-owned enterprises, such as China National Petroleum Corporation and Sinopec Group. They control the whole process of mining, transportation and selling natural gas. Due to the high cost, pipeline controllers are not willing to transport gas when gas hydrate can produce gas in large scale. Therefore, bargaining power of suppliers of gas hydrate market is weak.

\subsubsection{Threat of Substitution}

The substitute for natural gas hydrates is biogas. It is estimated that over $90 \%$ of biogas in China is produced in rural areas. The main development model of rural biogas in China is small-sized household biogas model; however, the number of medium-to-large biogas plants has been increasing since 2001 . Between 2001 and 2012, the Chinese government invested 34.6 billion Yuan for biogas development, of which 25.6 billion Yuan (74\% of the total subsidies) was put used for biogas development of rural households [43]. In 2013, biogas production in domestic rural areas is 15.78 billion cubic meters. Animal manure and straws are the main fermentation material, which are abundant in China. In addition, there are still many restrictions for the future development of biogas in China, the technical difficulties on pretreatment, biogas purification, etc. Meanwhile, the lack of reasonable pricing mechanism, the transportation for fermentation material and other aspects are barriers that hinder the development of biogas. As concluded from the development status of biogas in China, it is a clean energy that is able to be put into recycling production. During the production process, biogas can produce methane, which is the same as natural gas hydrate. Meanwhile, wheat straw biogas is of special significance. As a useless agricultural byproduct, the traditional way to deal with wheat straw in China is to burn it, which will lead to serious environmental problems. Wheat straw biogas is of great energy efficiency and the future development of wheat straw biogas is able to relieve the environmental pollution caused by wheat straw burning. However, biogas has not been fully developed due to condition strains, but with its promising future, we treat it as the substitute for natural gas hydrate. 


\section{Institutional Arrangement}

Under "the Twelfth Five-year Plan", China has established "Natural Gas Development in Twelfth Five-year Plan". The Central Government explicitly proposed to strengthen investigation and evaluation on gas hydrate and carry out trial mining experiments in a timely manner; exploration and exploitation of gas hydrate are included in the domestic development plan as well. However, in terms of gas hydrate development, China requires sound institutional arrangements. This paper builds a cooperation and policy framework to accelerate gas hydrate development. The institutional arrangement is shown in Figure 9.

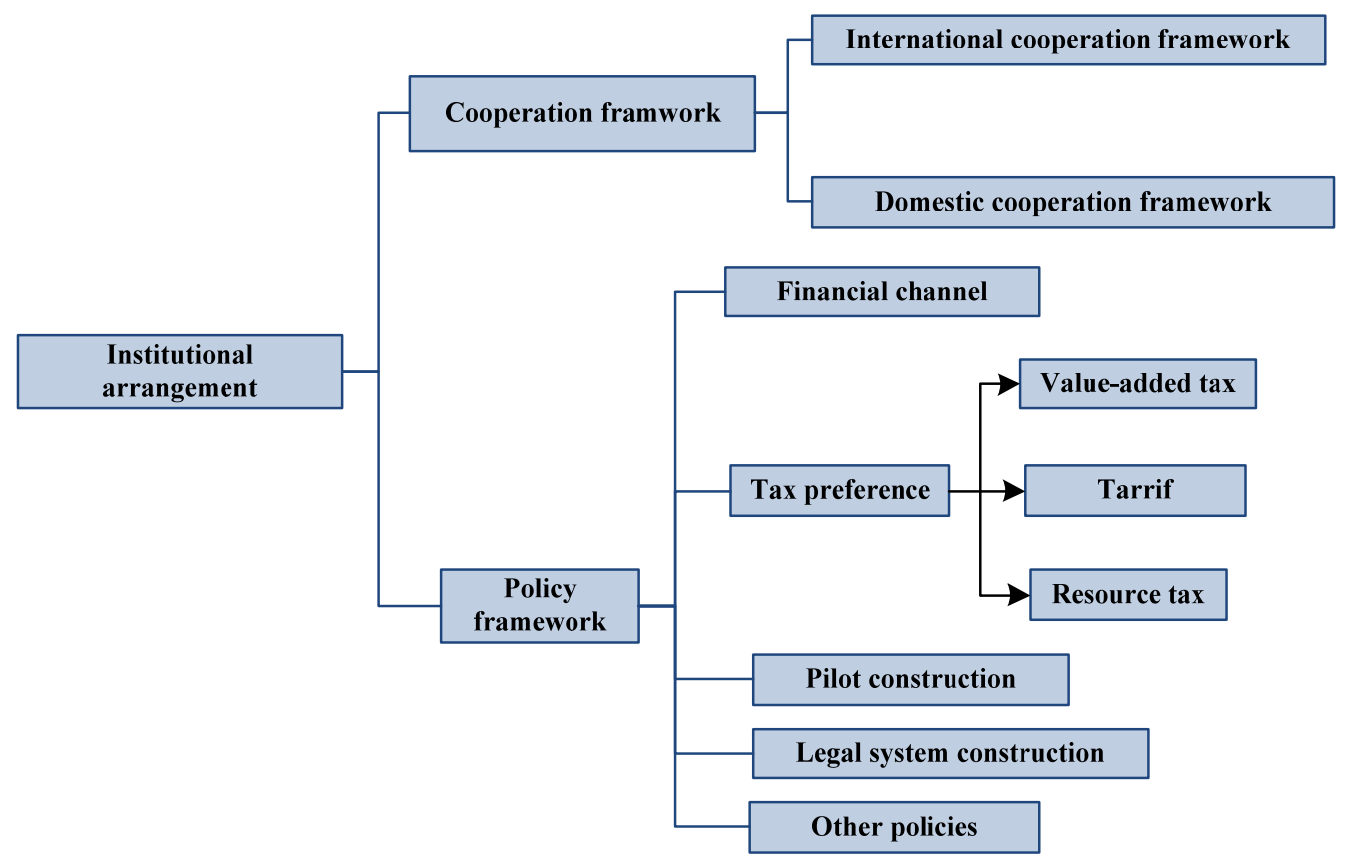

Figure 9. Institutional arrangement for natural gas hydrate development.

\subsection{Cooperation Frameworks}

\subsubsection{International Cooperation Frameworks}

For international cooperation framework, Chinese government should cooperate with developed countries like the United States, Japan, etc. In terms of gas hydrate field exploration, China has abundant combustible reserves, broad natural gas market and cheaper labor, while the U.S. and Japan has solid legal system and advanced technology; they can provide complementary advantage to promote domestic gas hydrate development, large enterprises and research intuitions can carry out joint research programs and sign bilateral or multilateral agreement with developed countries. In the agreement, parties share resource, information, technology, funds, and equipment to some extent, and each country in the agreement must be responsible for their duties. According to profit distribution mechanism, profit earned from the program should be distributed according to comprehensive input value, which is determined by investment, technology, resources, exploitation field provision and other aspects. Therefore, China can draw lessons from foreign policy and introduce advanced technology to shorten the gap between the U.S. and Japan of gas hydrate. The international framework is shown in Figure 10. 


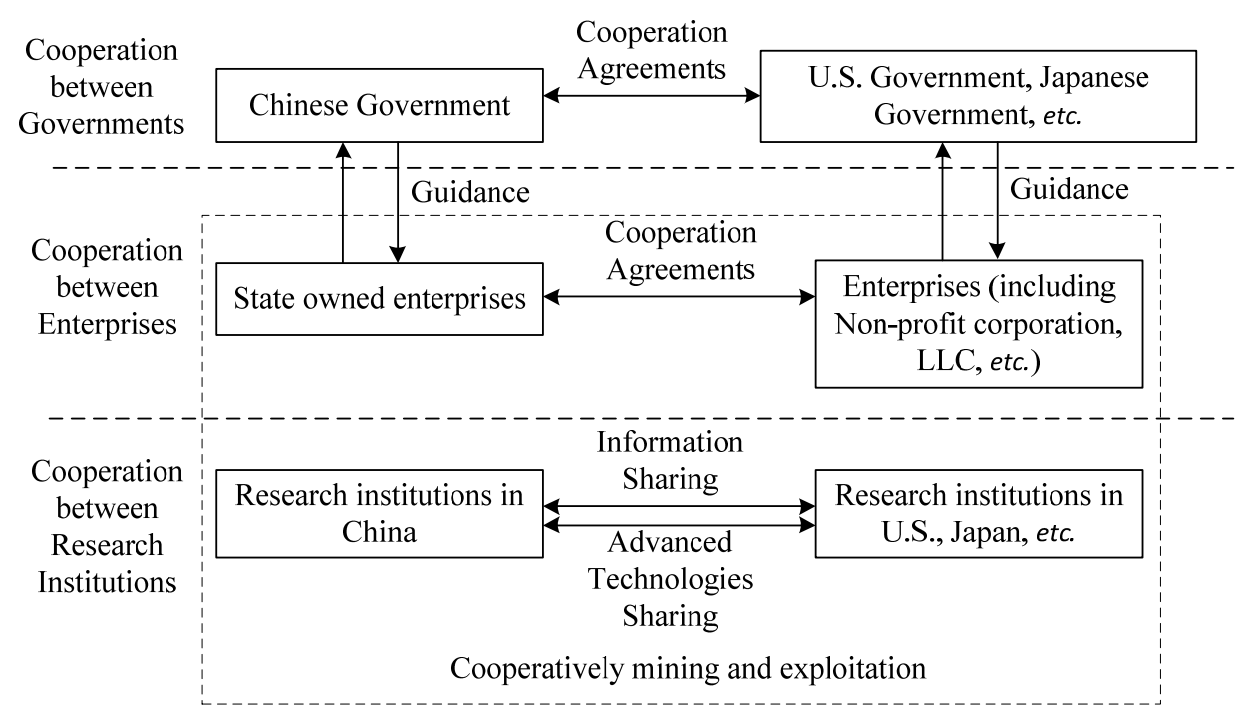

Figure 10. International cooperation frameworks.

The international cooperation framework includes three parts:

- Cooperation between Governments: All cooperation between all levels should be carried out following the guidance of governments. Hence, the cooperation agreements between Central Governments should be carried out first. The agreements may not be in detail, but should be instructive to the agreements between enterprises.

- Cooperation between enterprises: Under the guidance of governments, agreements between enterprises should be made. These agreements should include profit sharing mechanism (which determines how to share earnings after commercial production) and feedback mechanism (which helps to further optimize the cooperation mode).

- Cooperation between research institutions: The information sharing and technologies sharing mechanism should be built to promote mutual improvement. Besides, mining and exploitation should proceed in enterprises and research institutions from both countries.

\subsubsection{Domestic Cooperation Frameworks}

There is a certain risk in the early development of gas hydrate market. Since its mining investment is much higher than that of conventional natural gas, enterprises that invest in the programs may not gain profit and even suffer deficits in the short term. Therefore, during early commercialization, the Chinese government should carry out reinforcement investment and establish a special research foundation to ensure a capital source. In order to apportion the costs, the government could encourage large-scale energy enterprises with strong risk resistance capacity to jointly invest in the programs. Based on the feedback mechanism, enterprises, governments and research institutions sign technical collaboration agreements; governments and enterprises supply financial and policy support for research institutions; and research institutions should provide scientific achievement in return. If research institutions cannot be responsible for their duty, the investors can terminate their agreement. To promote technical breakthroughs, technicians in related fields should be introduced, while enterprises provide postgraduates and doctors for research institutions to keep abreast of the most professional development information. After setting up the technical foundation of industrial realization, the market can attract investment from small- and medium-sized enterprises; they are encouraged to bear technical and environmental risks. Subsequently, large-scale commercial production experiments are carried out to promote gas hydrate development in China. The domestic cooperation framework can be seen in Figure 11. 


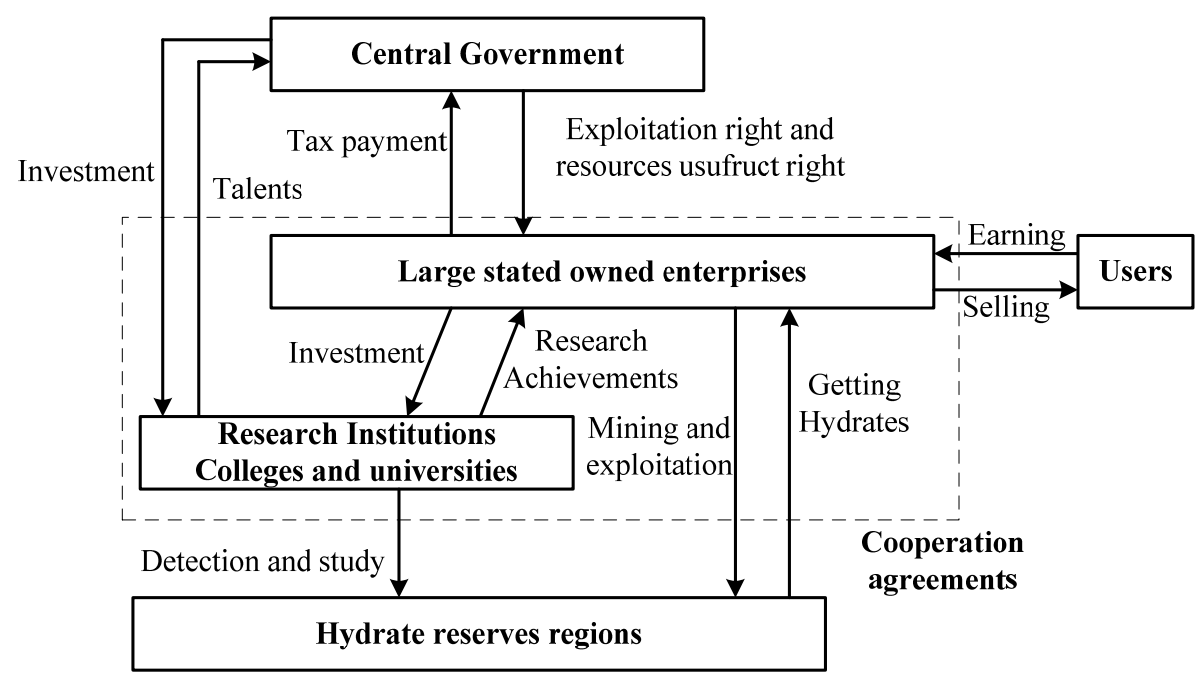

Figure 11. Domestic cooperation frameworks.

The figure above shows the possible policy and profit framework of China's natural gas hydrates mining and exploitation. The framework includes:

- The Central Government should carry out related policies to give the resource exploitation and usufruct rights to large state owned enterprises and invest in research institutions, colleges and universities.

- Research institutions, colleges and universities will actively perform technology studies and cultivate talents for governments and enterprises.

- Large state owned enterprises should invest in research institutions and form cooperation agreements to perform mining and exploitation in hydrate reserves regions. After extracting hydrates, these enterprises can sell them to users to earn profit and pay taxes to the Central Government in return.

Note that there is no commercial production and selling of hydrates in China yet. Hence, the right-handed part of framework is of great urgency to provide research basis for commercial production.

\subsection{Policy Frameworks}

For policy framework, the government should gradually strengthen financial investment and tax preferential policy to support gas hydrate development in China. Establishing special research foundation and carrying out tax exemption and preferential policies for gas hydrate to encourage enterprises. In addition, solid legal system should be built to supervise related service and guarantee normal operation. To reduce development risk, pilot cities are chosen to develop in advance.

\subsubsection{Financing Channels}

The government should establish special research foundation for gas hydrate. In addition, financial channels and means should be enlarged to fulfill the demand for funds. Taking the experience of shale gas development in the U.S. as reference, China should seek private-equity firms for equity investment, promote sourcing financing from commercial banks, and encourage small- and medium-sized enterprises to provide related service.

\subsubsection{Tax Preference}

In the preliminary stage of commercial production of gas hydrate, the government should give tax preference to related enterprises. For income taxes and value-added taxes, government should 
expand value-added tax deduction scope of enterprises that have gas hydrate services, reduce income taxes rates, or even exempt enterprises from tax. For tariff, when the key equipment and techniques for gas hydrate are imported into China, they should be exempt them customs. For resource tax, the government should give exemption to this tax of certain percentage; enterprises should be exempt from prospecting and mining rights fees. Moreover, the government should give subsidies to those mining enterprises during gas hydrate production.

\subsubsection{Pilot Construction}

Several pilot cities in gas hydrate-rich regions, according to resource endowment, current technical situation and natural gas demand, should be chosen. Local governments should establish specialized agencies to supervise services and give policy support. When pilot cities operate normally, the program should be expanded throughout the country.

\subsubsection{Legal System Construction}

Since there are no particular laws or regulations for the gas hydrate industry chain, a solid regulation system for gas hydrate must be established to strengthen supervision on gas hydrate exploration and exploitation. The legislation should include environmental protection legislation, industry promoting legislation, administrative legislation and mineral resources legislation as well as other legislations.

\subsubsection{Other Polices}

In order to promote industrial realization of gas hydrate, the government should establish particular strategy for gas hydrate development to provide the overall goal, guiding ideology and development path of gas hydrate development. In addition, the government should increase financial support for scientific research projects and make preferential policies to encourage technological innovation.

\section{Conclusions}

The goal of China's energy sector reform is to replace conventional fossil energy with clean and recyclable energy. Hence, under the broad context of energy sector reform in China, domestic natural gas hydrate has a relatively promising future in the market. On the one hand, China has abundant reserves of natural gas hydrate, approximately double the conventional natural gas reserve. On the other hand, domestic production cannot satisfy the increasing energy demand. However, lagging behind Japan and the United States, related technologies for natural gas hydrate exploitation are immature. Recently, domestic research mainly focuses on the formation conditions, reservoir-forming mechanisms and exploitation technologies. In addition, the cost to produce natural gas is high; hence, it has no price advantage.

This paper has analyzed natural gas hydrate development potential from four aspects, policy, technology, society and economy, comprehensively, as illustrated in the passage, gas hydrate is an emerging clean energy and is recognized socially as new-type energy to replace petroleum and other conventional energy. The Chinese Government attaches great importance to gas hydrate and proposes short-term goals and tasks on investigation, exploration, trial mining and technological research, but lacks a long-term development strategy and industrialization deployment. In addition, domestic research mainly focuses on South China Sea and Qinghai-Tibet permafrost regions, related studies are still in early development stage; and even though China has not yet not realized any trial mining, major breakthroughs have been made on reservoir-forming, resource investigation and other aspects. Under the condition of policy and funds permission, natural gas hydrate has broad market prospect, but there are certain market barriers. Rapid development of non-conventional gas including shale gas, $\mathrm{CBM}$ and tight stone gas as well as new energy sources such as biomass gas have become the strong competitors of natural gas hydrate. 
Author Contributions: All authors have contributed equally to the design of the research, data collection and analysis and the final preparation of the manuscript.

Conflicts of Interest: The authors declare no conflict of interest.

\section{References}

1. Makogon, Y.F. Natural gas hydrates e a promising source of energy. J. Nat. Gas Sci. Eng. 2010, 2, 49-59. [CrossRef]

2. Zheng, R.; Li, S.; Li, Q.; Hao, Y. Using similarity theory to design natural gas hydrate experimental model. J. Nat. Gas Sci. Eng. 2015, 22, 421-427. [CrossRef]

3. Lu, S.-M. A global survey of gas hydrate development and reserves: Specifically in the marine field. Renew. Sustain. Energy Rev. 2015, 41, 884-900. [CrossRef]

4. China Economic Net. Global natural gas hydrates development status. Available online: http://intl.ce.cn/ zhuanti/jcast/200903/18/t20090318_18538170.shtml (accessed on 16 May 2016).

5. People's Daily Online. The sleeping 'energy king': Natural gas hydrate has a long way to go. Available online: http:/ / energy.people.com.cn/n/2014/0106/c71661-24033024.html (accessed on 16 May 2016).

6. Sun, Y.; Li, J.; Wang, Q. Development and industrialization prospect of natural gas hydrate. Rev. Econ. Res. 2014, 50, 13-16, 31.

7. Yi, Z. Research on exploitation prospect of gas hydrate of southern Qilian Basin, Qinghai Province. Master's Thesis, China University of Geosciences, Beijng, China, 2014.

8. An, L.; Wen, Z.; Xie, Y.; Li, W. Research status of natural gas hydrate in permafrost areas of China. Res. Environ. Eng. 2014, 28, 5-9.

9. Zhu, Y.; Lu, Z.; Xie, X. Potential distribution of gas hydrate in the Qinghai-Tibetan Plateau. Geo Bull. China 2011, 30, 1918-1926.

10. Lu, Z.; Zhu, Y.; Zhang, Y.; Wen, H.; Li, Y.; Jia, Z. Basic geological characteristics of gas hydrate in Qilian Mountain permafrost area, Qilian Province. Miner. Depos. 2010, 29, 182-191.

11. Wei, W.; Zhang, J.; Wei, X.; Wang, Y. Resource potential analysis of natural gas hydrate in South China Sea. Prog. Geophys. 2012, 27, 2646-2655.

12. Trung, N.N. The gas hydrate potential in the South China Sea. J. Pet. Sci. Eng. 2012, 88-89, 41-47. [CrossRef]

13. Gong, Y.; Yang, S.; Wang, H.; Liang, J.; Guo, Y.; Wu, S.; Liu, G. Gas hydrate reservoir characteristics of Shenhu Area, north slope of the South China Sea. Geoscience 2009, 23, 210-233.

14. Zhu, Y.; Zhao, S.; Lu, Z. Resource potential and reservoir distribution of natural gas hydrate in permafrost areas of China. Nat. Gas Ind. 2011, 31, 13-18.

15. Lu, Z.; Zhu, Y.; Zhang, Y.; Wen, H.; Li, Y.; Wang, P. Estimation method of gas hydrate resource in the Qilian Mountain permafrost area, Qinghai, China-A case of the drilling area. Geol. Bull. China 2010, 29, 1310-1318.

16. Wang, Z.; Qu, H.; Jian, Z. Natural gas hydrates development status and prospect in China. Energy Conserv. 2010, 29, 4-6.

17. Wu, N.; Liang, J.; Wang, H.; Su, X.; Song, H.; Jiang, S.; Zhu, Y.; Lu, Z. Marine gas hydrate system: State of the art. Geoscience 2008, 22, 356-362.

18. Mohebbi, V.; Behbahani, R.M. Experimental study on gas hydrate formation from natural gas mixture. J. Nat. Gas Sci. Eng. 2014, 18, 47-52. [CrossRef]

19. Su, Z.; Cao, Y.; Yang, R.; Wu, N.; Yang, S.; Wang, H. Analytical research on evolution of methane hydrate deposits at Shenhu area, northern China Sea. Chin. J. Geophys. 2012, 5, 1764-1774.

20. Zhu, Y.; Zhang, Y.; Wen, H.; Lu, Z.; Wang, P. Gas hydrate in the Qilian Mountain permafrost and their basic characteristics. Acta Geosci. Sin. 2010, 31, 7-16.

21. Su, Z.; Moridis, G.J.; Zhang, K.; Wu, N. A huff-and-puff production of gas hydrate deposits in Shenhu area of South China Sea through a vertical well. J. Pet. Sci. Eng. 2012, 86-87, 54-61. [CrossRef]

22. Chong, Z.R.; Yang, S.H.B.; Babu, P.; Linga, P.; Li, X.-S. Review of natural gas hydrates as an energy resource: Prospects and challenges. App. Energy 2016, 162, 1633-1652. [CrossRef]

23. Chen, J.; Wang, Y.-H.; Lang, X.-M.; Fan, S.-S. Energy-efficient methods for production methane from natural gas hydrates. J. Energy Chem. 2015, 24, 552-558. [CrossRef]

24. Janicki, G.; Schlüter, S.; Hennig, T.; Deerberg, G. Simulation of subsea gas hydrate exploitation. Energy Procedia 2014, 59, 82-89. [CrossRef] 
25. Zhang, Y.; Liang, J.; Li, K.; Wang, H.; Li, X.; Wu, J. Research progress of drilling coring and mining on the permafrost natural gas hydrates in China. Procedia Eng. 2014, 73, 362-367.

26. Tian, S. The evolution course of Japan's combustible ice. Petro. Petrochem. 2013, 5, 5-9.

27. Luo, C. Japan's methane hydrate development today and advances. Sino Glob. Energy 2013, 18, 30-33.

28. Zhang, W. Combustible ice: The energy which can change the future. Ecol. Econ. 2014, 30, 3-7.

29. Rutqvist, J.; Moridis, G.J.; Grover, T.; Silpngarmlert, S.; Collett, T.S.; Holdich, S.A. Coupled multiphase fluid flow and wellbore stability analysis associated with gas production from oceanic hydrate bearing sediments. J. Pet. Sci. Eng. 2012, 92-93, 65-81. [CrossRef]

30. Liu, X.; Pan, Z.; Wang, Y.; Shang, L.; Li, P. Research progress in exploration and development methods of natural gas hydrate. Contemp. Chem. Ind. 2013, 42, 958-960.

31. Zhang, H. Research situation and prospects of flammable ice as a clean energy. Appl. Energy Technol. 2014, 8, $54-58$.

32. China's Industrial Information Network. Energy consumption condition of China in 2014. Available online: http:/ / www.chyxx.com/industry/201509/343642.html (accessed on 16 May 2016).

33. Zhang, J.; Wei, W.; Wang, H. Research on gas hydrate and its development techniques. Nat. Gas Technol. 2009, 3, 67-69.

34. Liang, J.; Wu, N.; Yang, M.; Wang, M.; Sha, Z. Resource estimate method of gas hydrate and its application. Geol. Bull. China 2006, 25, 1205-1210.

35. Sohu News. The U.S. invested huge funds on natural gas hydrate trail mining in Alaska. Available online: http://news.sohu.com/20121113/n357493729.shtml (accessed on 16 May 2016).

36. Deng, X.G.; Wu, L.S.; Fu, S.Y.; Wu, N.Y. The research of natural gas hydrates in northern South China Sea. J. Mar. Sci. 2008, 26, 67-74.

37. Song, Y.; Yang, L.; Zhao, J.; Liu, W.; Yang, M.; Li, Y.; Liu, Y.; Li, Q. The status of natural gas hydrate research in China: A review. Renew. Sustain. Energy Rev. 2014, 31, 778-791. [CrossRef]

38. Wu, Z.; Zhang, G.; Zhu, Y.; Lu, Z.; Chen, Y. Progress of gas hydrate investigation in China offshore. Earth Sci. Front. 2003, 10, 177-189.

39. Zhang, G.; Xu, H.; Liu, X.; Zhang, M.; Wu, Z.; Liang, J.; Wang, H.; Sha, Z. The acoustic velocity characteristics of sediment with gas hydrate revealed by integrated exploration of 3D seismic and OBS data in Shenhu area. Chin. J. Geophys. 2014, 57, 1169-1176.

40. Pei, J.; Wang, Q.; Zhang, X. Effective anomaly research on Marine CSEM detection of natural gas hydrate. Oil Geophys. Prospect. 2015, 50, 177-183.

41. Wang, Q. The CSEM Response of Submarine Gas Hydrates Research. Master's Thesis, Ocean University of China, Qingdao, China, 2014.

42. Tang, Z.; Hu, Y.; Guo, Q.; Guo, Z.; Wei, T. Advances in natural gas hydrate exploration and development technology. Prog. Geophys. 2015, 30, 805-816.

43. Yang, J.; Zeng, F.; Cheng, H.; Gao, J. Hydraulic lifting mining method for gas hydrate exploitation in the South China Sea. Henan Sci. 2015, 33, 785-790.

44. Vedachalam, N.; Srinivasalu, S.; Rajendran, G.; Ramadass, G.A.; Atmanand, M.A. Review of unconventional hydrocarbon resources in major energy consuming countries and efforts in realizing natural gas hydrates as a future source of energy. J. Nat. Gas Sci. Eng. 2015, 26, 163-175. [CrossRef]

(c) 2016 by the authors; licensee MDPI, Basel, Switzerland. This article is an open access article distributed under the terms and conditions of the Creative Commons Attribution (CC-BY) license (http://creativecommons.org/licenses/by/4.0/). 